\title{
Strategy for the Development of Kampung Sasirangan as Edutourism Village
}

\author{
Nasruddin, Ellyn Normelani ${ }^{*}$, Rosalina Kumalawati \\ Department of Geography Education, Faculty of Teaching and Education Science, Lambung Mangkurat University, \\ Banjarmasin, Indonesia
}

\begin{abstract}
Kampung Sasirangan is one of the centers of traditional textile production of Banjarese called Sasirangan in South Kalimantan. Sasirangan was produced by the local community in the home industry scale with traditional process and production. The aim of the research is to identify and develop strategy to develop Kampung Sasirangan as an edutourism destination. The methods consist of direct observation in the home industry of Sasirangan traditional textile, in-depth interview, literature study, and focus group discussion. Research result shows that strategy to create edutourism sites of Sasirangan textile should include local community and local government participation. The Sasirangan product should be able to create a competitive product, reasonable prices, and high quality of the textile product. To provide edutourism attraction for educational purposes, it is important to provide a program for tourist to directly observe the traditional process to make Sasirangan. A guide from local people or craftsmen was important to ensure the interpretation of the traditional process was delivered properly. In such a case, the community development is crucial. The local government should be able to promote community development program through the establishment of a community group which is work in edutourism in the village. There also important to provide training, working capital, production tools, and assistance in promotion and marketing.
\end{abstract}

Keywords: Edutourism, traditional textile, Sasirangan.

\section{INTRODUCTION}

Traditional fabric produced by Banjarese in South Kalimantan is one of the intangible cultural heritage of Indonesia. This traditional textile called Kain Sasirangan was produced by local community in Banjarese village, through the traditional process. Like many form of Indonesian fabric, these traditional textile identified has high cultural value, represent the important spiritual and economic value [1]. This traditional textile is one of the ten important commodity of South Kalimantan Province. As far, Sasirangan textile has been marketed and sold as textile and cloth. The Sasirangan textile has been sold as a souvenir of tourism in South Kalimantan.

Threats to the Sasirangan textile, however, comes from textile which area produced through modern technology. Modern textiles have rich in terms of the motif and cheap. Support for technology and modern machines influence the massive production textile [2].

Using tourism as education media has been promoted widely. Tourism has been reported as potential strategy to promote biodiversity conservation, cultural preservation, and local economic development. Tourism also contributes

\footnotetext{
* Correspondence Address:

Nasruddin

E-mail : ellynnormelani80@gmail.com

Address : Lambung Mangkurat University, Brigjen Haji Hasan Basri, Banjarmasin 70124
}

to local community development. The term of ecotourism has been proposed to illustrate the alternative of tourism, which can support biodiversity conservation, local culture conservation, and local economic development. The recent definition of ecotourism argues that education is important part of ecotourism. In such a case, it is clear that interpretation is an important part of the recent ecotourism program and activity. Through ecotourism, it is expected that local culture and tradition were promoted to the global community, especially the young generation [3].

Using tourism as education tools are also known as Edu-Tourism [4,5,6]. In edutourism, the student traveling to a particular area, which provides material to increase student understanding about some particular subject. Through edutourism, it is expected students increase their knowledge and perspective on particular subjects and issues. Edu-tourism has been reported as a significant strategy to increase student awareness. Edutourism provides opportunities to learn directly, and therefore it is important to increase student knowledge [7,8,9].

The area with potential resources for education programs should develop a strategy to meet Edu-tourism market needs. Planning and development strategies are a crucial factor to ensure the sustainability and competitiveness of tourism destinations, especially in the high competition era of the tourism business. The 
proper strategy will provide a blueprint for the significant action to meet destination objectives [10]. Scholars point out that one of the important methods to build the proper strategy is based on the community and local government perspectives. The objectives of the study were to describe the strategy for the development of the Sasirangan production area as a sustainable and competitive edu-tourism destination.

\section{METHODS}

Before to the focus group discussion, authors visit Sasirangan Village to get permission and general information related to the objective of the study. Meeting with villages leader and traditional textile producers were implemented to collect basic information regarding the recent status of Sasirangan textile production. The observation of villages and their daily life were implemented. The observation also conducted in traditional textile production sites, which was focused on observing methods and processes of Sasirangan textiles production.

In-depth interviews implemented to collect data and information related to the aspects of traditional textile production. Observation was done at 11 production sites in Sasirangan Village. The key informant of this research includes the staff of the Tourism Office of Banjarmasin City and the local community in Sasirangan Village. Data were analyzed descriptively. The location of study is shown in Fig. 1.
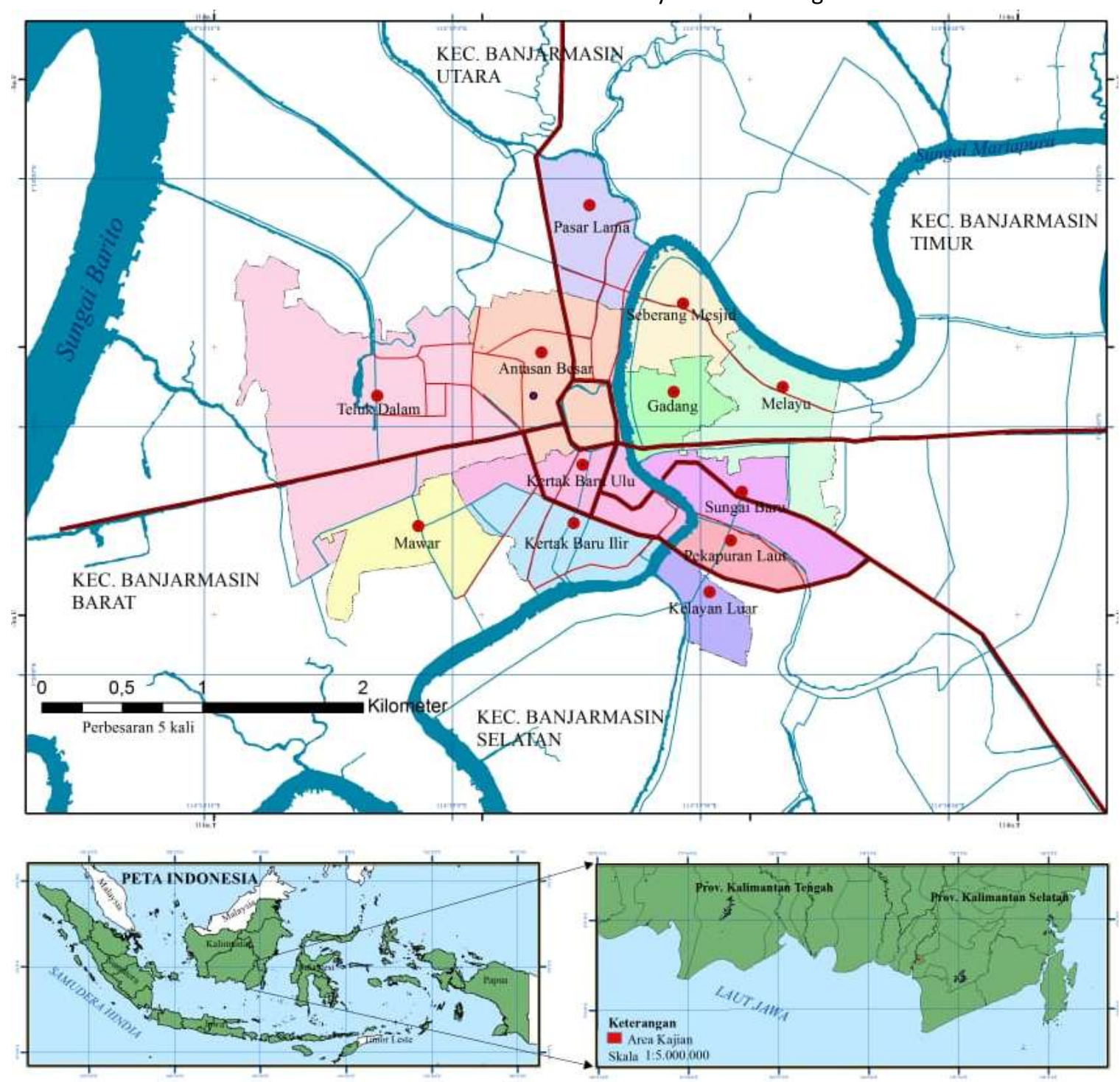

Figure. 1 The location of Sasirangan villages (Kampung Sasirangan) in Banjarmasin Source: Shella Oktaviani Sholehah, 2018. 
Development of Kampung Sasirangan as Edutourism Village

(Nasruddin et al)

\section{RESULT AND DISCUSSION \\ The Sasirangan Textile}

In 2018, 64 home industry producing Sasirangan textile recorded in Banjarmasin city, in which 11 home industry found in Sasirangan Village. There were some important steps to produce Sasirangan textiles, in which traditional techniques have been implemented in production process. Sasirangan textile is one of the traditional textiles created and produced by the local community in South Kalimantan, called Banjarese. There are numerous motifs and colors of the textile, represent the rich idea of Banjarese to produce unique Sasirangan (Fig. 2).

Sasirangan is well-known as a cloth with diverse and exotic colors. Interestingly, a different area often produces different motifs and colors, lead to the high diversity of the Sasirangan motif in South Kalimantan. The traditional process has been influencing the diversity of motif and color of Sasirangan cloth.
The motif also subjects of consumer order, in which consumers able to request specific motifs and colors.

There are some steps in the production of Sasirangan textiles. According to the informant, the first step was drawing motif in sheets of cloths. In the drawing step, a pencil used to draw a motif. The next was include sewing cloth, or in Bajarese called menyirang with the needle, then pulled out to create wrinkles impact to the sheets of cloth. The sheets of cloth were colored using the dye solution.

After the coloring process, the sheets of cloth washed using cold water, and the tied cloths were released to produce motifs. To ensure the durability of color and motif in sheets, local craftsmen of Sasirangan use a chemical solution called fixanol. The final step for the process was include drying. The dry by air recommended ensuring the durability and high quality of Sasirangan. The complete steps shown in Fig. 3.

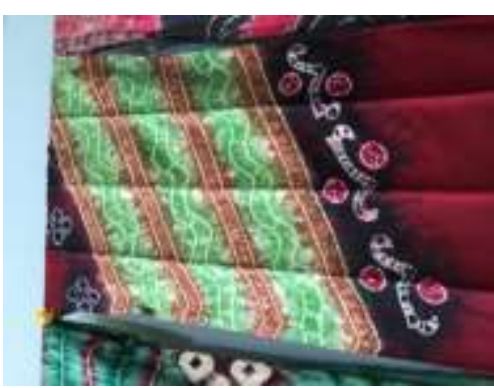

Naga Balimbur and Jumputan combination

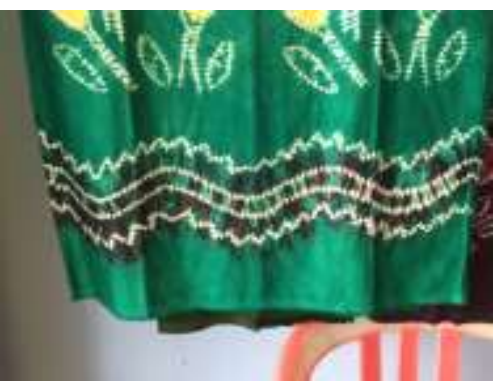

Kulat Karikit and Naga Balimbur

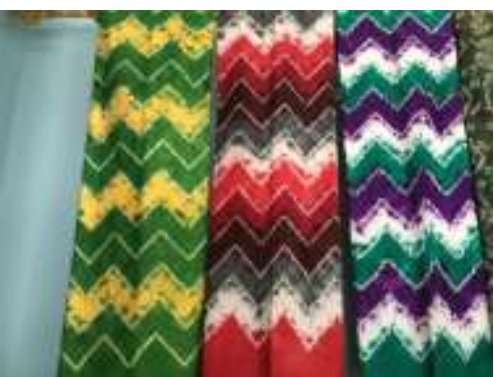

Iris Pudak

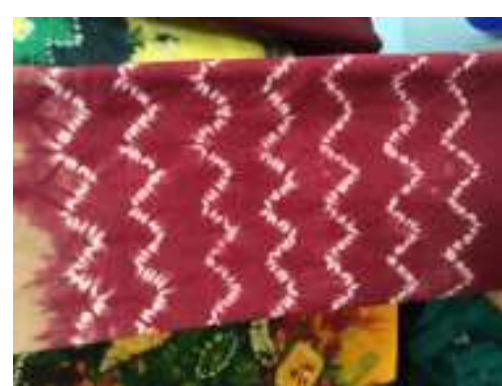

Kulat Karikit

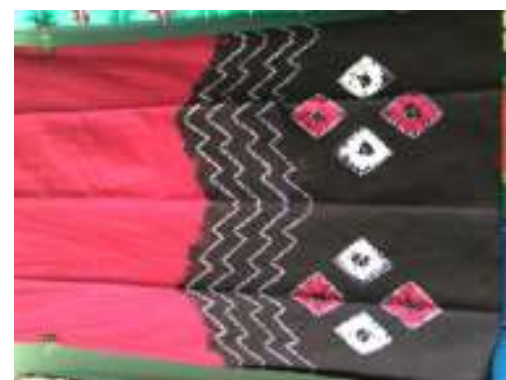

Kulat Karikit and Gagatas

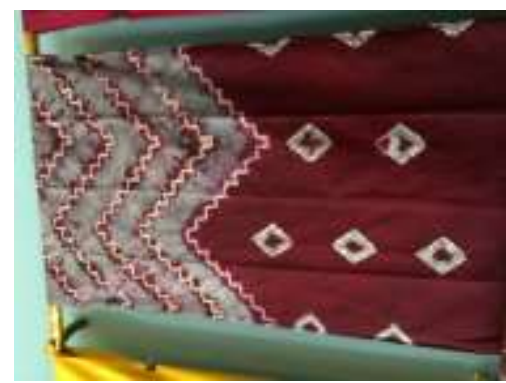

Iris Pudak combined with Gagatas

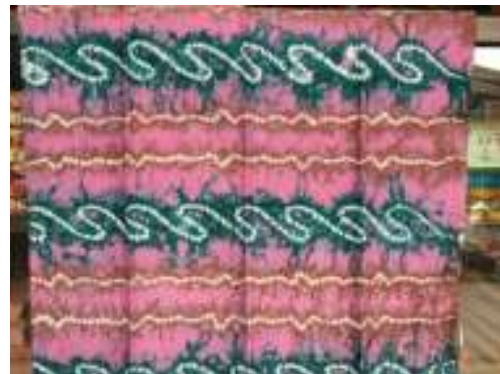

Ombak

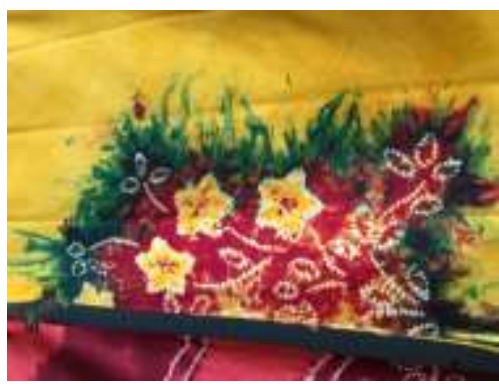

Modern Kangkung Kaombakan

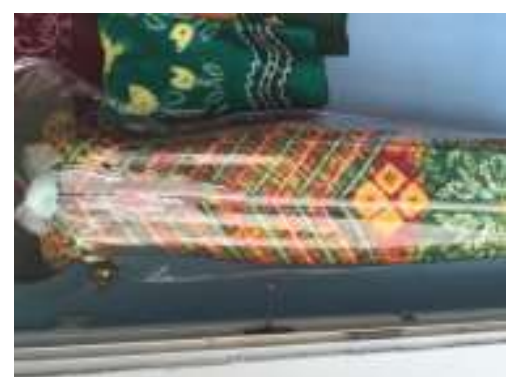

Turun Dayang

Figure 2. Some motif of Sasirangan textile produced by Banjarese in Kampung Sasirangan

(Source: Afni Zulaika Pratiwi, 2018) 


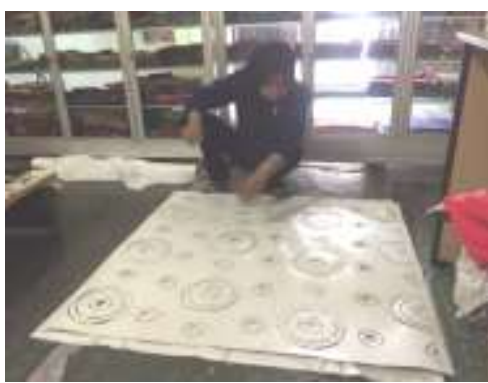

Drawing motif

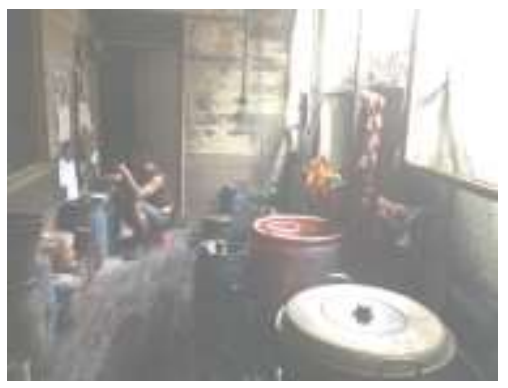

Coloring process

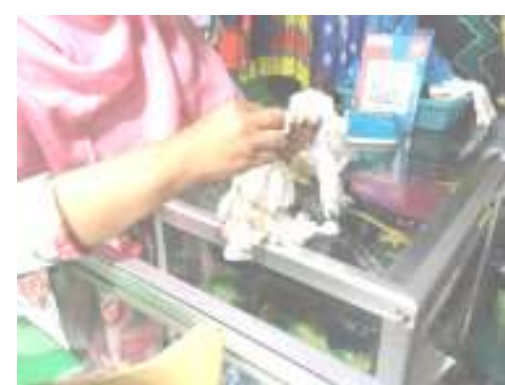

Sewing cloth

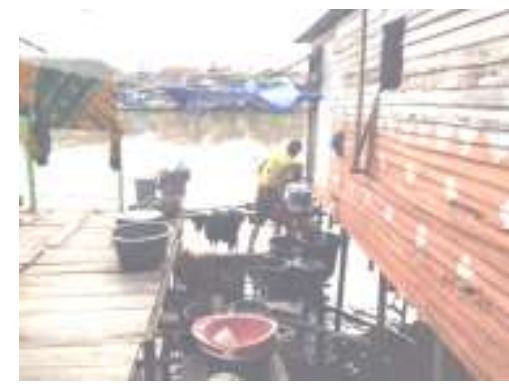

Washing

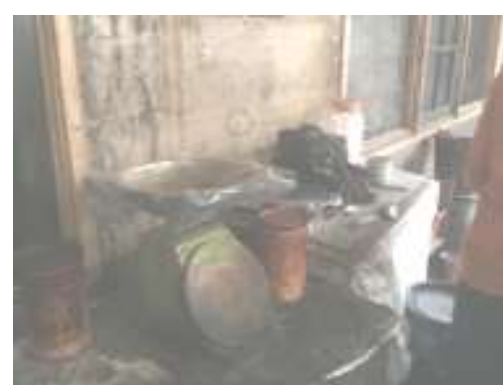

Dye preparation

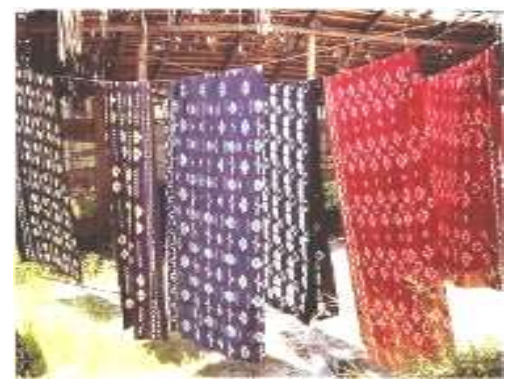

Air dry

Figure 3. Some illustration of traditional processing of Sasirangan

(Source: Afni Zulaika Pratiwi, 2018)

\section{Strategy for the Edu-tourism Development}

The result of the FGD outlined into two strategy approaches, namely strategy related to the community and strategy that belong to the local government responsibility. According to the discussion participant, these strategies should be integrated and basically cannot be separated from each other.

\section{Local Community Strategy}

For the local community strategy, the important strategy explained as follows. First, it is important to create an attraction which is able to attract tourist to actively learn about the history and traditional techniques to produce Sasirangan. Tourists should have direct experiences with Sasirangan processing, from material preparation motif design and processing (Fig. 3). Attention to produce interesting Sasirangan, however, should be paid in dye materials. As far, the coloring solution to produce a motif in a sheet of fabric consist of chemical dye. It was reported that the coloring process results in significant waste [11]. In which it potentially contributes to environmental pollution. The alternative for reducing pollutant material included promoting natural dye [12].

Second, it is important to produce Sasirangan with high-quality standard products and processes. It is especially important in the era of the high competition of the textile product. Problems, however, found in the human resources, especially traditional craftsmen to produce Sasirangan. There are important issues to produce Sasirangan following high standard products in an environmentally acceptable process.

Developing a new motif and color combination also becomes an important aspect to be considered in production. The innovation appears to be crucial issues in the development of Sasirangan fabric. The recent innovation of local craftsmen includes making numerous goods based on Sasirangan, such as shoes, sandals, a woman's bag, pencil box, head cap, table-cover, bed linen, and other product following market demand. Innovation is the key to the success of a product in market competition. In Indonesia, the innovation to produce numerous goods is one of the strategies to increase the market sales of small and medium enterprises products $[13,14]$.

Thirds strategy included promoting tourism awareness programs (Sadar Wisata) to the community in Sasirangan village. Seven principles of tourism awareness promoted by the Indonesia government (Sapta Pesona) should be introduced. It includes secure, orderly, clean, fresh, beauty, hospitality, and memory. The local atmosphere to meet seven principles of Sapta Pesona should be introduced and implemented 
as one of the keys to the success of tourism in Sasirangan Village [15].

\section{Local Government Strategy}

Local government strategy in the development of Sasirangan villages as an edutourism area includes the following explanation. First, it is important to local government to promote local community organizations to initiate and manage tourism in the community level. The development of Sadar Wisata community seems to be crucial. In such a case, training and other activity to improve local community knowledge and skill in tourism implementation are important. As far, these action has been poorly implemented. Other issues related to the local community tourism development related to the ability of the local community to find and manage potential attraction becomes an attractive tourism object. It is especially important as an effort to diversify tourism products for educational purposes [10].

The second strategy includes improving human resources knowledge and skill in fabric production. The ability of human resources in managing potential resources is one of the keys to community-based tourism. It is especially important in rural tourism, in which human resources sectors are important. Rural tourism has been identified to yield many economical benefits to the resident [16].

The third strategy includes providing capital to ensure the sustainability of craftsmen in producing Sasirangan. The production of Sasirangan requires many different kinds of material, in which it is often difficult to access by the local craftsmen. The small enterprise's group in villages often lack capital, skill, and knowledge. Several factors have been identified as factors to the competitiveness of products in the market, including packaging. Post-production tools are also important, especially for packaging fabric products.

Fourth, it is crucial for local government to assist the marketing aspect of Sasirangan. The local community often has a limitation in skill, knowledge, and networking to sell their product. In a situation where access to the market difficult, it is important to support marketing intensively.

\section{CONCLUSIONS}

The four strategies of the development of Sasirangan edutourism villages established by the local community and local government are as follows: 1) Establishing community awareness to tourism, 2) Developing tourism attraction which provides opportunities to enjoy Sasirangan processing and production, 3) Increasing product competitiveness through human resources development to produce traditional textile with local wisdom characters, and 4) Providing capital support and marketing assistance.

\section{REFERENCES}

[1] Gittinger, M. 1979. Splendid symbols: textiles and tradition in Indonesia. The Textile Museum. Washington, DC.

[2] Hill, H. 1992. Indonesia's textile and garment industries: Developments in an Asian perspective (No. 87). Institute of Southeast Asian.

[3] Hakim, L. 2004. Dasar-dasar ekowisata. Bayumedia.

[4] Holdnak, A. and S. Holland. 1996. Edutourism: vacationing to learn. Parks and Recreation, 72-75.

[5] Gibson, H. 1998. The educational tourist. Journal of Physical Education: Recreation and Dance 69 (4),32-34.

[6] Vieira, O. A. D. 2018. Developing edutourism in an urban indigenous community: the case of Aldeia Bananal (Brasília-DFBrazil). International Journal of Tourism Anthropology 6(2), 133-153.

[7] Smith, C. and P. Jenner. 1997. Educational tourism. Travel and Tourism Analyst 3, 6075

[8] Ma'rifah, D. R., and I. G. P. Suryadarma. 2015. Penyusunan panduan Edutourism Hutan Wisata Tlogo Nirmolo guna memunculkan karakter peserta didik Kelas X. Jurnal Inovasi Pendidikan IPA 1(2), 126137.

[9] Hayati, R. S. 2017. Edutourism Taka Bonerate National Park through scientific approach to improve student learning outcomes. Journal of Physics: IOP Conference Series 812(1), 012023.

[10] Attar, M., L. Hakim and B. Yanuwiadi. 2013. Analisis potensi dan arahan strategi kebijakan pengembangan Desa Ekowisata di Kecamatan Bumiaji-Kota Batu. Journal of Indonesian Tourism and Development Studies 1(2), 68-78.

[11] Utami, U. B. L. and R. Nurmasari. 2007. Pengolahan limbah cair sasirangan secara filtasi melalui pemanfaatan arang kayu ulin sebagai adsorben. Jurnal Sains MIPA 13(3), 190-196. 
[12] Fauziyah, N. and L. Hakim. 2015. Plants as natural dyes for Jonegoroan Batik processing in Jono Cultural Tourism Village, Bojonegoro, East Java. Journal of Indonesian Tourism and Development Studies 3(2), 41-44.

[13] Setiawan, H. 2012. Pengaruh orientasi pasar, orientasi teknologi dan inovasi produk terhadap keunggulan bersaing usaha Songket skala kecil di Kota Palembang. Orasi Bisnis 8(2), 12-19.

[14] Dewi, N. W. P. N. and G. Suparna. 2017. Peran inovasi dalam memediasi pengaruh orientasi kewirausahaan terhadap keunggulan bersaing industri kain Endek. EJurnal Manajemen Universitas Udayana 6(9), 5144-5174.

[15] Rahmawati, S. W., S. Sunarti, and L. Hakim. 2017. Penerapan Sapta Pesona pada desa wisata (analisis persepsi wisatawan atas layanan penyedia jasa di Kampung Wisata Kungkuk, Desa Punten, Kota Batu). Jurnal Administrasi Bisnis 50(2), 195-202.

[16] Purmada, D. K., and L. Hakim 2016. Pengelolaan desa wisata dalam perspektif community based tourism (studi kasus pada Desa Wisata Gubugklakah, Kecamatan Poncokusumo, Kabupaten Malang). Jurnal Administrasi Bisnis 32(2), 15-22. 